\title{
Pembuatan Sabun Cair Cuci Piring untuk Pengembangan Wirausaha Karang Taruna di Pondok Ungu Permai Sektor V, Babelan, Bekasi Utara
}

\author{
Andi Turseno ${ }^{1^{*}}$, Rifda llahy Rosihan ${ }^{2}$, Oki Widhi Nugroho ${ }^{3}$, Sonny Nugroho \\ $\mathrm{Aji}^{4}$, Sumanto ${ }^{5}$ \\ 1,2,3,4,5Teknik Industri, Fakultas Teknik, Universitas Bhayangkara Jakarta \\ Raya, JI. Perjuangan Raya, Marga Mulya, Bekasi Utara, Jawa Barat, 17143. Telp/fax. \\ (021) 88955871, andi,turseno@dsn.ubharajaya.ac.id, \\ rifda.ilahy@dsn.ubharajaya.ac.id, oki.widhi@dsn.ubharajaya.ac.id, \\ sonny.nugroho@dsn.ubharajaya.ac.id, sumanto@dsn.ubharajaya.ac.id
}

*Korespondensi : andi,turseno@dsn.ubharajaya.ac.id

Diterima: 16 November 2021 ; Review: 18 November 2021 ; Disetujui: 26 Desember 2021 ; Diterbitkan: 31 Desember 2021

\begin{abstract}
The need for liquid dish soap is increasing because some people have started to switch from using cream soap for washing dishes. In addition, the use of liquid dish soap is easier and more effective in cleaning stains on kitchen utensils. The basic ingredient of liquid dish soap is a surfactant chemical compound which has a function as a stain remover on kitchen utensils. The purpose of this community service is to provide knowledge to youth organizations in terms of making liquid soap to develop youth entrepreneurs at Ponduk Ungu Permai Sector V, Babelan, North Bekasi. The method used in this community service activity is discussion, presentation, knowledge sharing, and the practice of making dish soap. The result of this community service is in the form of a finished product of liquid dish soap according to the method provided.
\end{abstract}

Keywords : Liquid dish soap, cream soap, surfactant, business development

\begin{abstract}
Abstrak
Kebutuhan akan sabun cuci piring cair meningkat dikarenakan beberapa masyarakat mulai beralih yang semula menggunakan sabun berbentuk krim sebagai sabun untuk mencuci piring kini beralih ke sabun cuci piring cair. Selain itu, penggunaan dari sabun cuci piring cair lebih mudah dan efektif dalam membersihkan noda pada peralatan dapur. Bahan dasar dari sabun cuci piring cair adalah senyawa kimia Surfactan yang memiliki fungsi sebagai pengangkat noda pada peralatan dapur. Tujuan dari pengabdian kepada masyarakat ini adalah untuk memberikan ilmu kepada karang taruna dalam hal pembuatan sabun cair untuk mengembangkan wirausaha Karang taruna di Ponduk Ungu Permai Sektor V, Babelan Bekasi Utara. Metode yang digunakan dalam kegiatan pengabdian kepada masyarakat ini adalah diskusi, pemaparan, sharing ilmu, dan praktik pembuatan sabun cuci piring. Hasil dari pengabdian kepada masyarakat ini berupa produk jadi sabun cuci piring cair sesuai dengan metode yang diberikan.
\end{abstract}

Kata kunci : Sabun cuci piring cair, krim sabun, surfactan, pengembangan usaha

\section{PENDAHULUAN}

Sabun merupakan bahan yang digunakan untuk mencuci, membersihkan, baik pakaian, perabotan, lantai, dan sebagainya yang bahan dasarnya merupakan campuran alkali dan trigliserida dari asam lemak (Sitorus \& Fitri, 2021). Bahan pembuatan sabun 
terdiri dari dua jenis yakni bahan baku utama dan bahan pendukung. Bahan utama dari pembuatan sabun adalah basa natrium atau kalium dan asam lemak. Sedangkan untuk bahan pendukung berupa pewangi, pelembut, pewarna dan lain-lain (Purwaniati et al., 2020). Bahan dasar sabun cair pada umumnya meliputi SLS, texapon, dan garam serta bahan aditif seperti parfum, pengawet, pengental dan zat perwarna (Sulistyaningsih \& Indah Pratiwi Pakpahan, 2020). Garam merupakan salah satu bahan yang berfungsi sebagai zat pengental dalam pembuatan sabun, Semakin banyak jumlah garam yang digunakan maka sabun yang dihasilkan pun semakin kental (Salamah et al., 2018).

Sabun mampu menghilangkan kotoran dan minyak karena didalamnya sabun terdapat struktur kimia yang bersifat hidrofil pada rantai ionnya dan bersifat hidrofobik untuk rantai karbonnya. Rantai hidrokarbon ini yang mengakibatkan molekul sabun secara keseluruhan tidaklah benar-benar larut dalam air. Tapi, sabun mudah untuk tersuspendi dalam air karena membentuk misel, yakni segerombolan molekuk yang rantai hidrokarbonnya mengelompok dengan ujung-ujung ionnya yang menghadap ke air (Supriyadi et al., 2020). Salah satu zat yang dapat membantu dalam mengangkat noda pada peralatan adalah surfactant. Surfaktan yang umum dipakai adalah surfaktan yang disintesis dari petroleum seperti petroleum sulfonat. Kelemahan penggunaan surfaktan ini adalah tidak tahan terhadap kadar salinitas yang tinggi, cenderung mencemari lingkungan karena sifatnya yang sulit didegradasi, harganya mahal, dan masih harus diimpor (Supriningsih, 2010). Tujuan dari pengabdian kepada masyarakat ini adalah mengembangkan wirausaha Karang Taruna Garuda 021 dengan memberikan pelatihan pembuatan sabun cuci piring cair.

\section{ANALISIS SITUASI}

Karang Taruna Garuda 021 merupakan karang taruna yang berada di Kelurahan Pondok Ungu Permai Sektor V, Babelan yang diketuai Muhammad Fakhri Kharis dan di bawah binaan Sudaryono yang merupakan Koordinator Pemuda \& Olahraga. Karang Taruna Garuda 021 memiliki divisi kreativitas dan wirausaha. Salah satu produk dari divisi ini adalah pembuatan sabun cuci piring cair. Namun produk sabun cuci piring cair yang diproduksi oleh divisi kreativitas dan wirausaha ini masih memiliki kekurangan yaitu busa yang dihasilkan kurang melimpah dan bau yang dihasilkan kurang tajam (kurang wangi). Dari hasil pengamatan itulah, pengabdian kepada masyarakat dengan program Pembuatan Sabun Cair Cuci Piring untuk Pengembangan Wirausaha Karang Taruna di Pondok Ungu Permai Sektor V, Babelan, Bekasi Utara ini dilakukan untuk mengurangi kekurangan dari sabun cuci piring cair tersebut.

\section{METODE PELAKSANAAN}

Pelaksanaan kegiatan pelatihan pembuatan sabun cuci piring cair ini dilakukan dalam beberapa tahap, yaitu:

a. Memberikan pemaparan mengenai bahan-bahan pembuatan sabun cuci piring cair

b. Diskusi berupa tanya jawab mengenai hal-hal yang berkaitan dengan pembuatan sabun cuci piring cair

c. Praktek pembuatan sabun cuci piring cair

d. Sharing session dalam mengenai pembuatan sabun cuci pring cair

\section{HASIL DAN PEMBAHASAN}

\subsection{Penyiapan Alat dan Bahan}

Kegiatan pengabdian kepada masyarakat ini dilaksanakan pada tanggal 6 November 2021. Peserta yang menjadi sasaran pada pelaksanaan kegiatan ini adalah Karang Taruna Garuda 021, Pondok Ungu Permai Sektor V, Babelan, Bekasi Utara.

Kegiatan ini dimulai dari persiapan alat dan bahan yang dibutuhkan untuk menghasilkan 5 liter sabun cuci piring cair yaitu: 


\section{Bahan :}

1. Surfactan $1196 \mathrm{gr}$

Surfactan 1 merupakan salah satu jenis Surfactan yang berbahan baku Metil Ester Sulfonat dari minyak nabati sehingga bahan baku ini lebih ramah lingkungan karena bahan dasar yang digunakan adalah minyak nabati (Supriningsih, 2010). Surfactan ini berbentuk seperti lembaran-lembaran tipis. Berbeda dengan texapon. Texapon merupakan surfactant yang memiliki bentuk seperti gel.

Sumber : Hasil Pelaksanaan (2021)

\section{Celosize (Bahan A)}

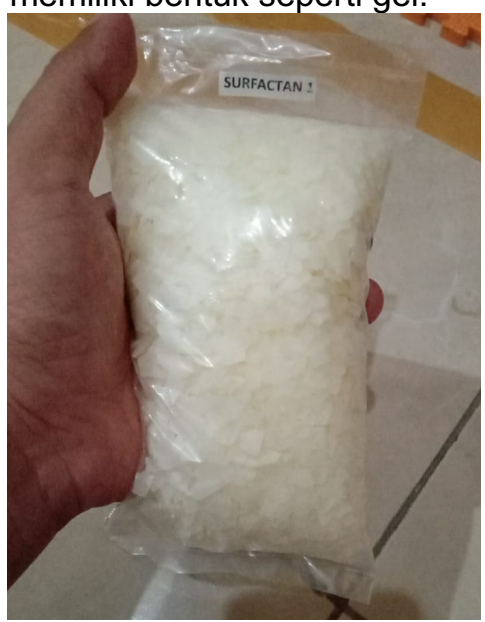

Gambar 1. Surfactan MES

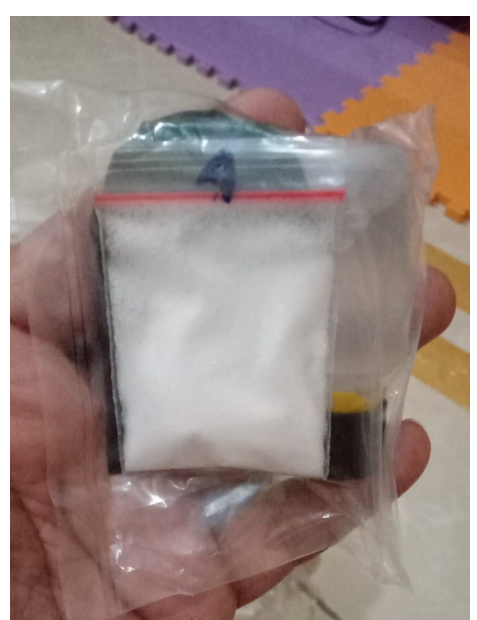

Gambar 2. Bahan A 
Andi Turseno, Rifda llahy Rosihan, Oki Widhi Nugroho, Sonny Nugroho Aji, Sumanto

Diterima : 16/11/2021 ; Review : 18/11/2021 ; Disetujui : 26/12/2021 ; Diterbitkan : 31/12/2021

3. $\mathrm{NaCl}($ Bahan B) 153gr

Sumber : Hasil Pelaksanaan (2021)

4. LABS (Bahan C) $224 \mathrm{gr}$

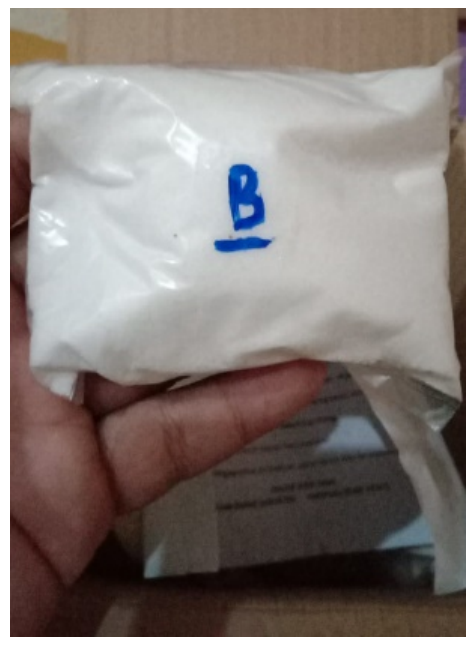

Gambar 3. Bahan B

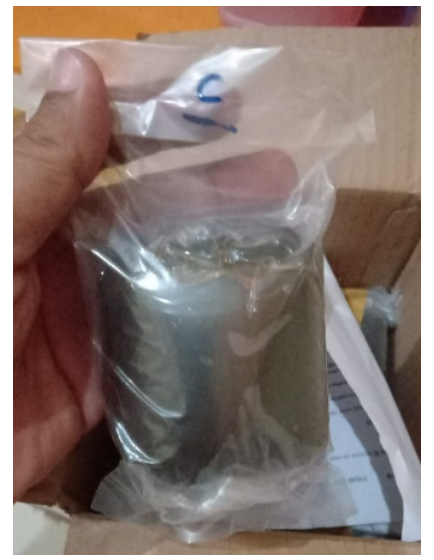

Sumber : Hasil Pelaksanaan (2021)

5. Citric Acid (Bahan D) $31 \mathrm{gr}$

Gambar 4. Bahan C

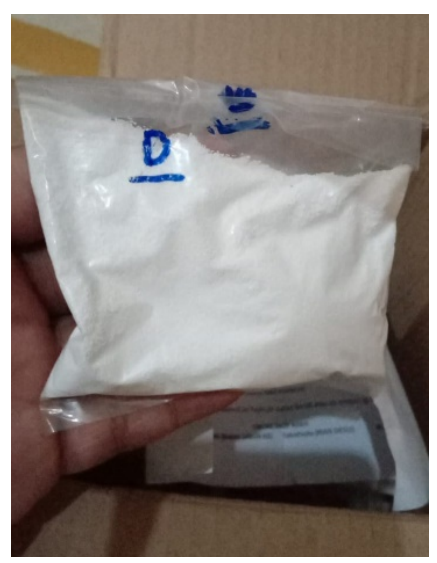

Sumber : Hasil Pelaksanaan (2021)
6. Pewarna
7. Pewangi Lemon Sunlight
8. Air Aquades

Gambar 5. Bahan D 
Alat :

1. Ember 25 liter (2 buah)

2. Pengaduk

Cara Pembuatan

1. Wadah 1 isi dengan 1 liter air panas (mendidih)

2. Wadah 2 berisi 4 liter air biasa

3. Larutkan bahan Surfactan 1 di wadah 1 yang sudah terisi air panas, aduk hingga larut sempurna

4. Tambahkan Bahan A ke Wadah 1, aduk hingga larut

5. Tambahkan Bahan B, ke wadah 1, aduk rata hingga mengental

6. Tambahkan Bahan $\mathrm{C}$, ke wadah 1, aduk rata hingga kekentalan berkurang

7. Tambahkan air ke wadah 1 sedikit demi sedikit dari wadah kedua air di wadah kedua habis. Jangan menambahkan air secara sekaligus.

8. Tambahkan pewarna, aduk rata

9. Tambahkan Bahan D, aduk hingga larut

10. Tambahkan pewangi, aduk rata

11.Diamkan +- 6 jam supaya homogen

12.Saring ketika akan dikemas

\subsection{Penyampaian Materi dan Praktik Pembuatan Sabun Cuci Piring Cair}

Kegiatan Pengabdian kepada Masyarakat ini diawali dengan pembukaan, yaitu sambutan-sambutan dari Ketua RW dan Pembina Karang Taruna Garuda 021. Acara ini dihadiri oleh pemuda karang taruna Garuda 021 dan warga Ponduk Ungu permai Sektor V RW 21.

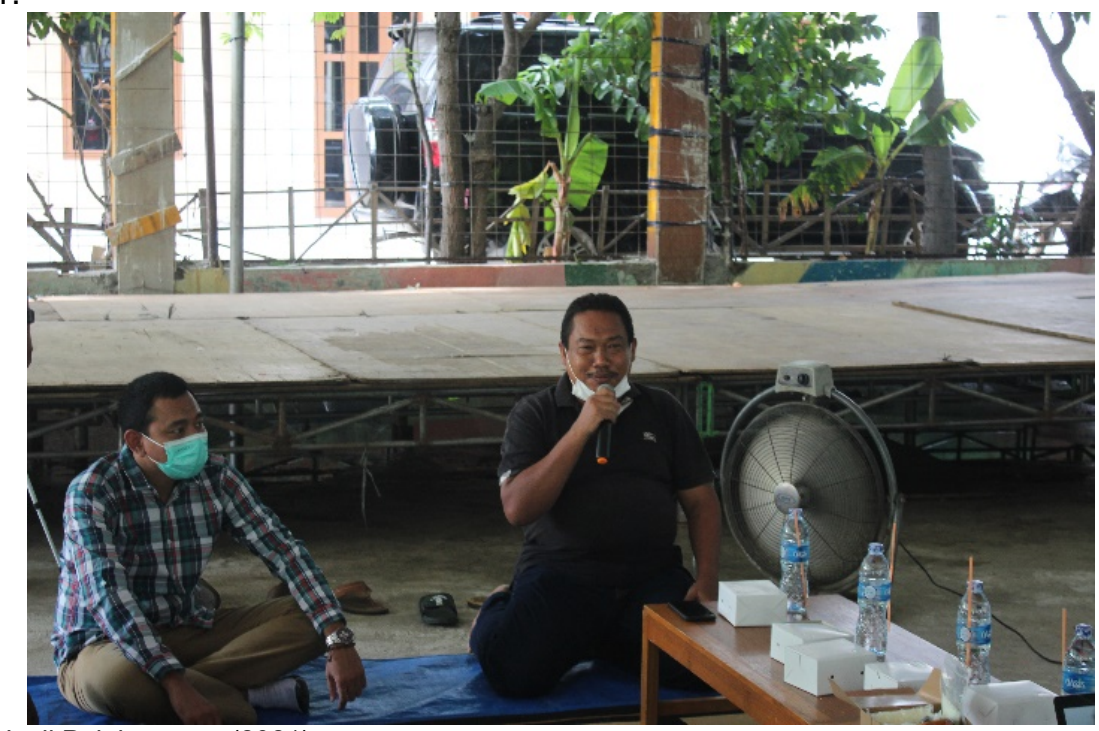

Sumber : Hasil Pelaksanaan (2021)

Gambar 6. Sambutan Ketua RW 


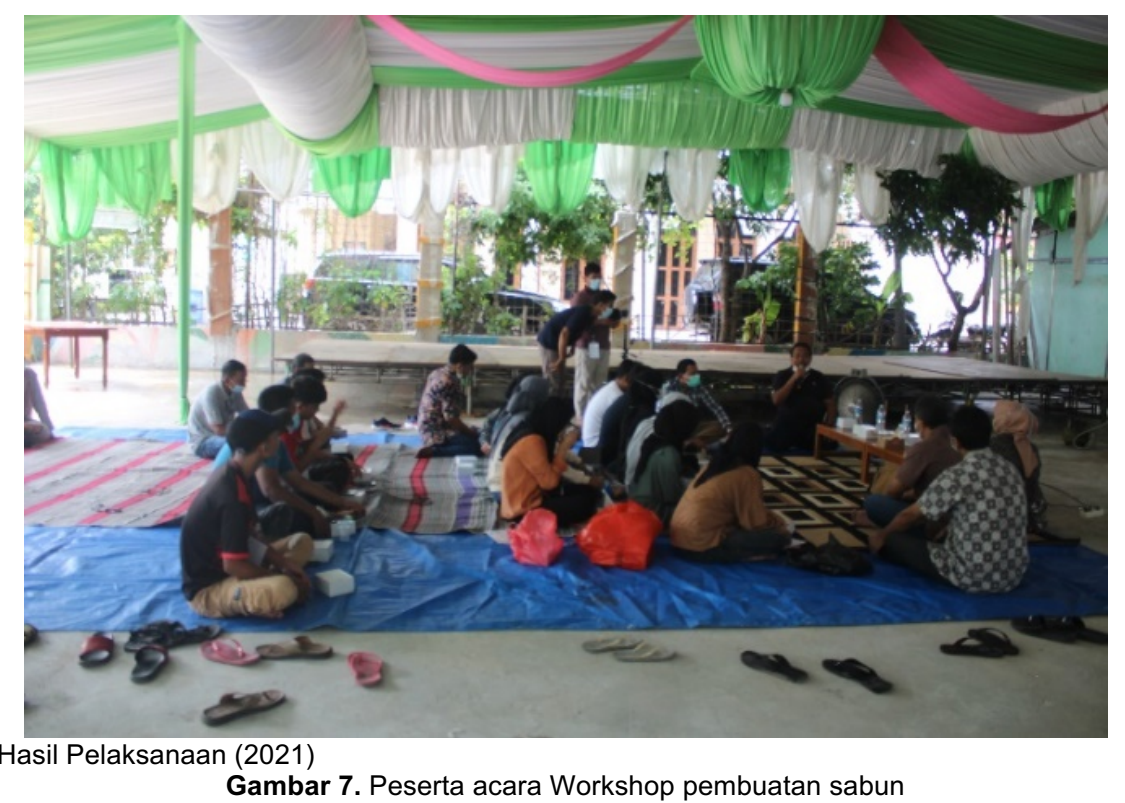

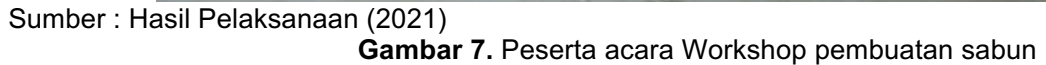

Sebelum dilakukan praktik mengenai teknik pembuatan sabun, terlebih dahulu diberikan pemaparan mengenai materi-materi yang berkaitan dengan pembuatan sabun, bahan pembuatan sabun, dan diskusi berupa tanya - jawab kepada peserta. Sebelumnya, karang Taruna Garuda 021 sudah memiliki produk berupa sabun cuci piring cair namun yang menjadi kendala mengenai bau dari sabun yang semakin lama semakin menghilang dan sedikitnya busa yang dihasilkan. Pemberian materi dan praktek ini merupakan sharing session untuk mengetahui bagaimana agar sabun cuci piring cair yang dihasilkan berbau wangi dan menghasilkan banyak busa.

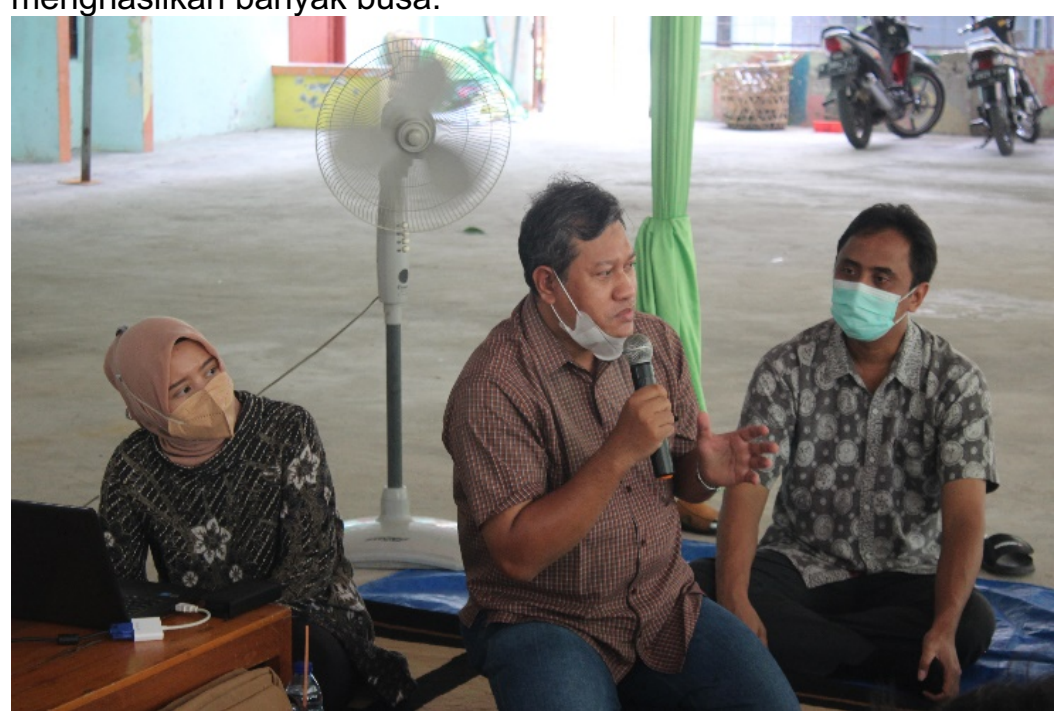

Sumber : Hasil Pelaksanaan (2021)

Gambar 8. Pemaparan Materi

Kegiatan Pengabdian kepada Masyarakat di Ponduk Ungu Permai Sektor V, Babelan, Bekasi Utara dilanjutkan dengan praktek pembuatan sabun cuci piring cair. Pembuatan sabun cuci piring cair dapat dilihat pada Gambar 9. 


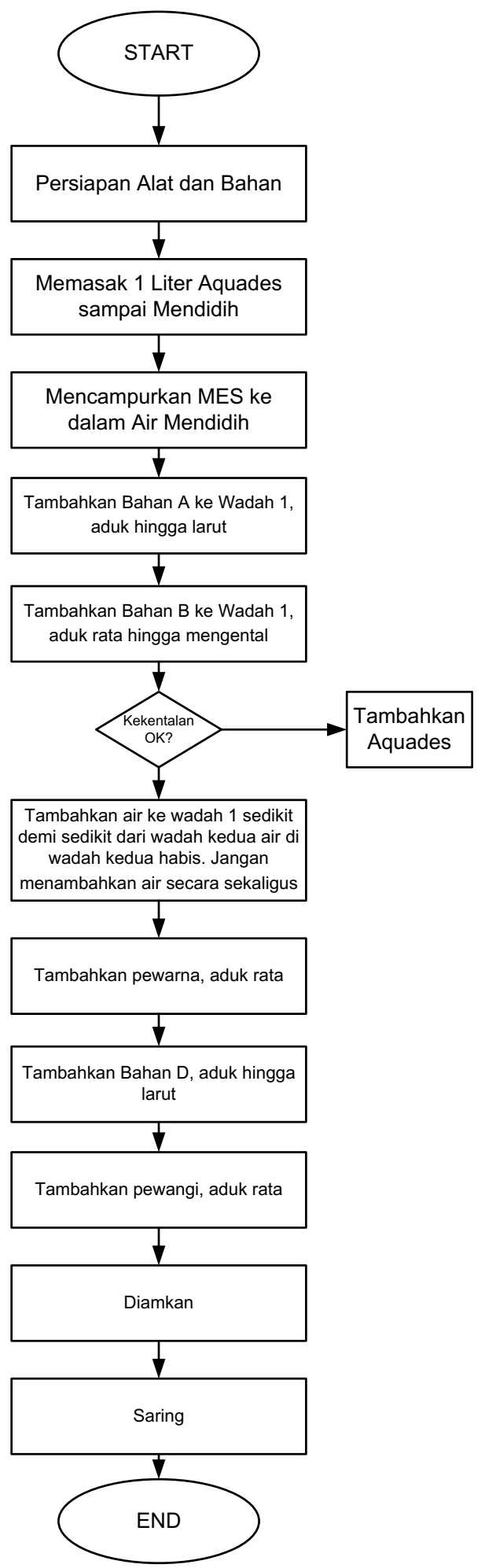

Sumber : Hasil Pelaksanaan (2021)

Gambar 9. Proses Pembuatan Sabun Cuci Piring Cair 


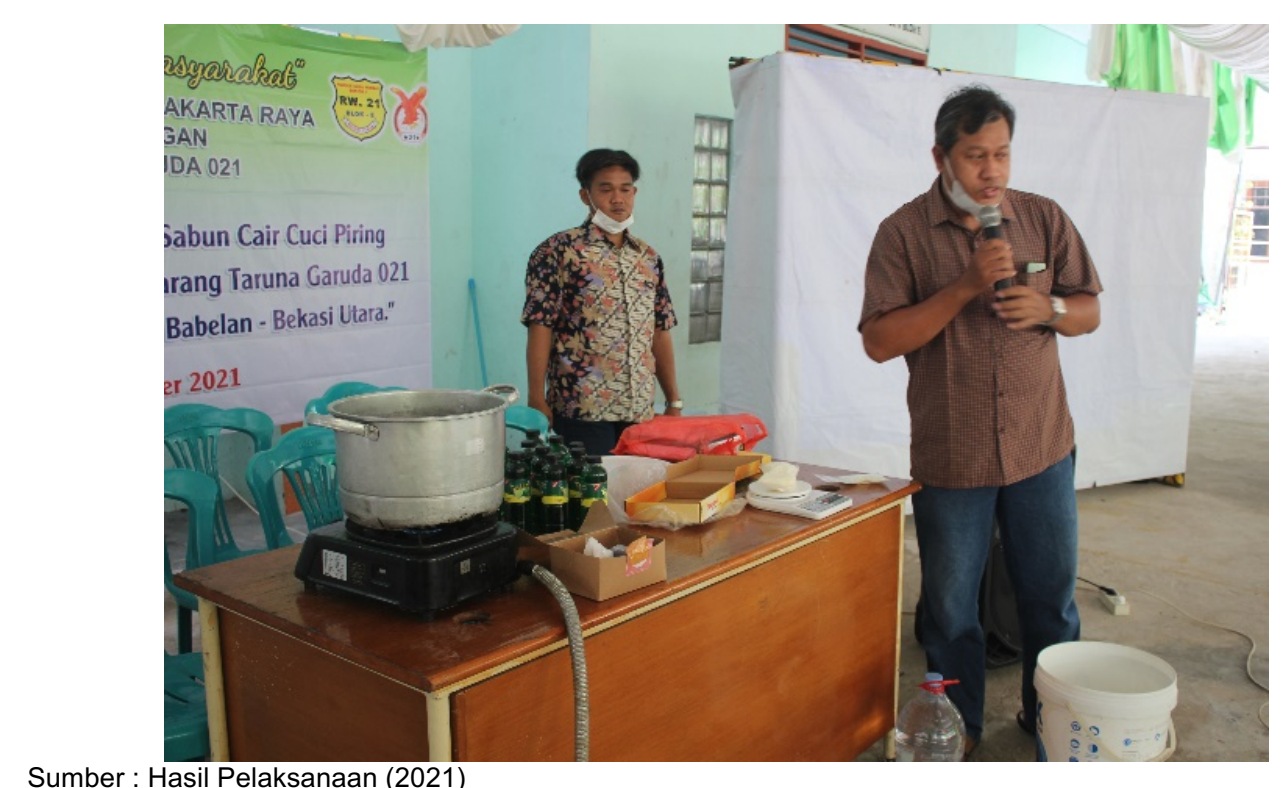

Sumber : Hasil Pelaksanaan (2021)

Gambar 10. Praktek Pembuatan Sabun Cuci Piring Cair

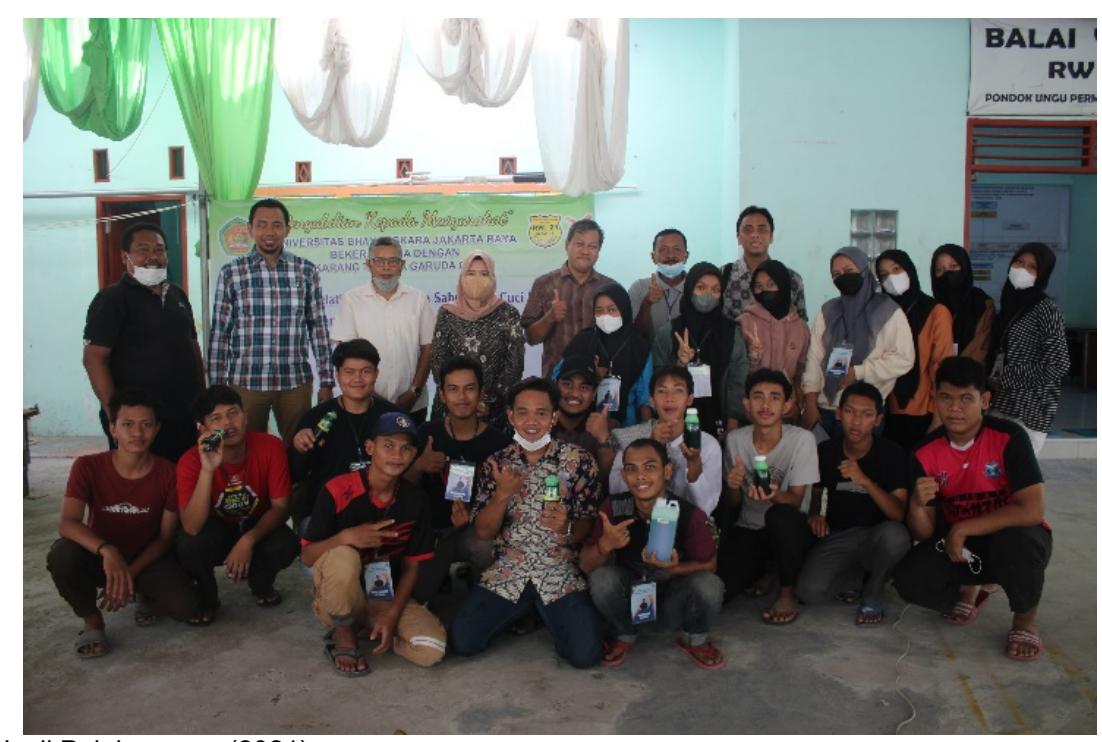

Sumber : Hasil Pelaksanaan (2021)

Gambar 11. Foto Bersama dengan Peserta 


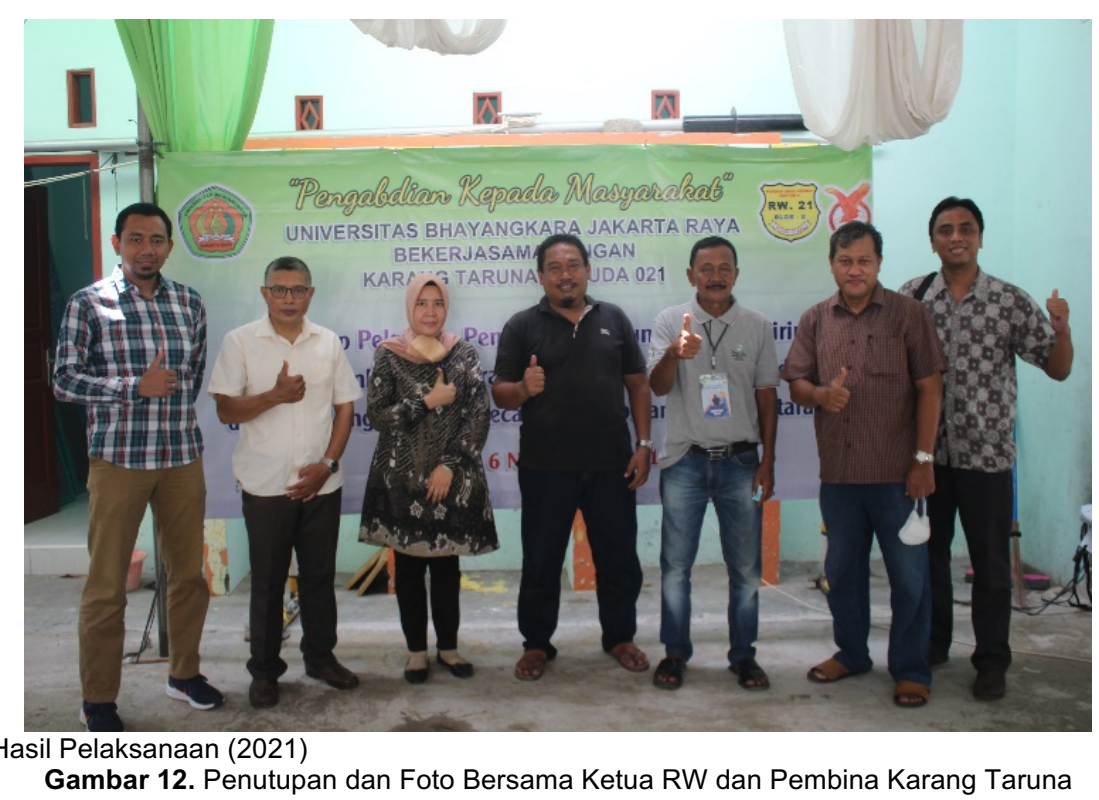

Hasil dari Kegiatan Pengabdian kepada Masyarakat di Ponduk Ungu Permai Sektor $\mathrm{V}$, Babelan, Bekasi Utara adalah produk sabun cuci piring cair dengan busa yang lebih lembut, banyak, dan bau sabun yang wangi.

\subsection{Evaluasi}

Dari kegiatan Pengabdian kepada Masyarakat di Ponduk Ungu Permai Sektor V, Babelan, Bekasi Utara berupa workshop pembuatan sabun cuci piring cair ditemukan beberapa kendala disamping produk sabun yang kurang wangi dan busa yang dihasilkan sedikit yaitu kendala mengenai pengemasan produk yang menghabiskan biaya yang cukup besar. Oleh karena itu diharapkan selanjutnya dapat dilakukan kelanjutan dari pengabdian kepada masyarakat berupa pengemasan produk sabun yang dapat memgurangi limbah plastik dengan biaya yang minimal dengan menggunakan botol PET atau plastik pouch dengan ukuran sesuai yang telah diperhitungkan.

\section{KESIMPULAN DAN REKOMENDASI}

Sabun yang dihasilkan pada acara pengabdian kepada masyarakat ini menghasilkan busa yang lembut dan banyak serta bau yang wangi. Lembutnya busa yang lembut dan banyak dihasilkan dari penggunaan bahan yang berbeda dari produk awal milik Karang Taruna Garuda 021 dan produk Pengabdian kepada Masyarakat. Bahan yang digunakan pada produk awal menggunakan bahan surfactant dengan jenis texapon. Sedangkan produk hasil pengabdian menggunakan bahan Surfactan 1. Bau yang semakin lama semakin hilang diakibatkan karena adanya kesalahan dalam proses pembuatan. Pewangi merupakan senyawa kimia yang mengandung alcohol sehingga jika diaduk terlalu lama maka campuran dapat menghasilkan panas dan pewangi menjadi menguap. Kedepannya diharapkan dapat dilakukan pengabdian lanjutan berupa pembuatan sabun cair jenis lain, pengembangan mengenai pengemasan produk yang memberikan nilai ekonomi.

\section{DAFTAR PUSTAKA}

Purwaniati, Emma Emawati, Anne Yuliantini, Winasih Rahmawati, \& Idar. (2020). Produksi Sabun Cuci Piring Dan Sabun Mandi Rumah Tangga Sebagai Upaya Peningkatan Kemandirian Masyarakat. Amaliah: Jurnal Pengabdian Kepada Masyarakat, 4(2), 145-151. https://doi.org/10.32696/ajpkm.v4i2.426

Salamah, S., Sulistiawati, E., \& Aktawan, A. (2018). Pelatihan Teknologi Kimia Terapan Pembuatan Sabun Cair Cuci Piring, Sabun Mandi Herbal Dan Tepung Ampas Kelapa Ibu-lbu 'Aisyiyah Ranting Perumnas Condong Catur, Depok, Sleman. Jurnal Pemberdayaan: Publikasi Hasil Pengabdian Kepada Masyarakat, 1(2), 465. 
https://doi.org/10.12928/jp.v1i2.326

Sitorus, Z., \& Fitri, H. (2021). PEMBUATAN SABUN PENCUCI PIRING SEBAGAI PELUANG USAHA BAGI IBU-IBU PKK DESA SEI ALIM HASSAK KECAMATAN SEI. 1(1), 21-25.

Sulistyaningsih, E., \& Indah Pratiwi Pakpahan. (2020). PEMBUATAN SABUN PENCUCI PIRING SEBAGAI PELUANG USAHA BAGI IBU PKK DUSUN PUTAT WETAN, DESA PUTAT, KECAMATAN PATUK, GUNUNGKIDUL. 3(2), 94-99.

Supriningsih, D. (2010). Pembuatan Metil Ester Sulfonat (MES) sebagai Surfaktan untuk Enhanced Oil Recovery (EOR). Universitas Indonesia.

Supriyadi, E., Dewanti, R. N., Taufik, Junaedi, \& Sofyan, S. (2020). PENYULUHAN DAN PELATIHAN PEMBUATAN SABUN CUCI PIRING. Jurnal Pengabdian Dharma Laksana Mengabdi Untuk Negeri, 3(1), 28-34. 